\title{
DEVIATIONS OF PATIENTS WITH DRUG ADDICTION VALUE AND MEANING SPHERE FUNCTIONING
}

DOI: 10.36740/WLek202004126

\author{
Oleksandr 0. Filts ${ }^{1}$, Kira V. Sedych ${ }^{2}$, Vitalii A. Lavrinenko ${ }^{2}$, Svitlana V. Mychailiv ${ }^{2}$ \\ 'LVIV DANYLO HALYTSKY NATIONAL MEDICAL UNIVERSITY, LVIV, UKRAINE \\ 2POLTAVA V. G. KOROLENKO NATIONAL PEDAGOGICAL UNIVERSITY, POLTAVA, UKRAINE
}

\begin{abstract}
The aim of this article is to study empirically drug addicts value-meaning sphere disorders.

Materials and methods: To study the drug addicts value-meaning sphere disorders indicators, Schwarz's «Value Questionnaire» and a structured interview of the respondents, aimed at studying the specifics of their meaning constructs, was used.

Results: Meaning structure disorders are analyzed on the basis of the constructs and images of fixed imagination, which are used by drug addicts to describe the role of the addictive agent in their life, description. The system of myths of drug addicts, which reflects their attempts to constructively justify changes in their life and behavior in the use of psychoactive substances and shows the existence of compensatory mechanisms in the psyche of drug addicts, is analyzed.

Conclusions: Value-meaning sphere functioning disorders play a significant role in the process of drug addiction formation, which is realized through the alteration of the value system, the presence of value conflict, the influence of images of fixed imagination and myths on the attitude to drug addiction.
\end{abstract}

KEY WORDS: drug addicts, value-meaning sphere of personality, addictive agent, images of fixed imagination of drug-addicts, disorders of value-meaning sphere of drug-addicted patients

\section{INTRODUCTION}

The process of formation and course of drug addiction is quite complex and involves a large number of factors, which can be generally defined as a combination of a complex of cognitive-affective disorders and the fixation and realization of pathological behavioral patterns. The system of value-meaning comprehension of reality, self, relationship «personality-addictive agent» and social reality is deformed in the group of drug addicts, in comparison with healthy personalities, characterized by the appearance of overvalued entities, the leveling of typical values for the individual.

Current research of the drug addiction factors and manifestations reflects the authors' efforts to understand the holistic process of drug addiction in the totality of its components. As O. V. Zmanovskaya [1] says, drug usage has a strong influence on human thinking processes. Drug addicts over time produce unproductive (protective) adaptation to life - a fixed, inflexible constructions of relationships with themselves, their loved ones (within the family) and with the outside world on the basis of the mechanism of alienation; attempts to resolve a difficult life situation in inappropriate, inadequate ways.

Patients with drug addiction are characterized by certain features of the meaning sphere, which are expressed in its structural and content characteristics. In the structure of the addicts' meanings, its general simplicity, conciseness, which signals a certain loss of vital meanings, it is noted. Particularly significant is the structural severity and incoherence of addicts meanings, the inability to build a hierarchy of meaningful structure, which is expressed in their perception of life as a series of unrelated situations that are not united by common goals, beliefs of the individual $[2,3,4,5,6]$.

Because of self-centeredness and simplicity of the meaning sphere, drug addicts have a predominance of following the urgent needs, focusing on its immediate satisfaction, acquiring psychological comfort, which is one of the most important values for them [6]. The actual needs of such people determine the meanings of concrete actions, and the complex, motivated nature of their actions is lost and the temporal perspective of the meaning reality is narrowed considerably. As a result of drug addiction, disorders of the meaning regulation of behavior, expressed in spontaneity, inability to realize meaningful installations in real activity, manifestation of specific protective mechanisms in the form of denial of the drug addiction occurance fact $[7,8]$. Drug addiction, which has a meaningful value as a narcotic drug, in the course of its development inevitably imposes a system of specific personal meanings that are determined by the characteristics of the drug to the subject [2]. As the consolidation of drug addiction as a way to meet the urgent needs of the system generated by the narcotic substance personal meanings acquires stability, rigidity, becoming a system of specific personality settings. The phenomenon of meaning-forming values of drug addicts selection is one of the main obstacles to the psychological 
rehabilitation of drug addicts [6]. Values corresponding to the semantic settings of the drug addicted person are accepted as substitutes for the drug, values which do not correspond to the meaning settings are rejected. According to the L. F. Shcherbina [7] research addictive personalities are characterized by such features of the meaning sphere as reduced level of meaning hierarchy: meaning constructs that influence personal change occupy low rank places in the structure of the motivational-meaning sphere. R. R. Garrifullin [3] notes that the meaningful orientations of drug addicts are subordinated to protective motivation. Their protective strategies are implemented in compensatory mechanisms and in denial of the very fact of drug addiction, which is not true.

O. O. Filts, K. V. Sedykh, S. V. Mikhailsv [9] have developed a five-component model of addiction development, according to which drug addiction develops in interaction of such elements of the addict's personality as motivation, memory, thinking, the physical component, emotions and fixed imagination. The predominant role in the additive process formation belongs to the fixed imagination, which they understand as an emotionally saturated image, which is created by the process of hypertrophying part of reality in the imagination and its completion in fantasy. During the impact of the agent addiction creates a specific «amalgam» - a fusion of emotion and image, which gains independent value. Fixed imagination in the process of addiction development is the center of circular connections between other psychic processes: emotions - through the over-emotional attitude to the object of addiction; memory, motivation and thinking - through the emergence of valuable ideas. At the same time, the specificity of this system is fixedness of imagination, attitude, ideas.

Given that the image of the imagination in content is the possibility of being an object (situation), then in the sphere of «desired in combination with emotional charge, we receive the possible and / or undesirable possible». This is manifested in the fact that, contrary to the logic of causation, the person considers real, admits to himself, to the realm of his experiences, what meets his desires, the content of thinking, in turn, is subordinated to emotions. A precious idea arises that creates the basis for planning specific actions; it also forms an internal action plan; life planning and programming. The emergence of precious ideas reflects the functioning of the content-forming function of the cognitive processes disruption, reflecting the disruption of cause and effect in the awareness of life and actions, the perceptions of content, entrenched in different objective and subjective aspects of human life.

As mentioned above, the process an addiction formation system creates a precious idea about the addiction object. The concept of precious ideas was put forward by S. Wernicke [10] to refer to individual judgments or groups of judgments, affectively saturated and of a stable, fixed nature. The precious idea in its development is increasingly captivating the patient's consciousness, and new precious ideas are joining it. It merges so much with the patient's personality that he or she is perceived as the only correct representation or system of representations that he or she actively defends. E. Kretschmer believed that a person was completely absorbed in painful precious ideas.

Precious ideas are characterized by the following major factors: 1) dominance in the psyche: precious ideas and personality merges, the idea and self-made rules begin to control the behavior of the individual. Adherence to the idea becomes dominant, other needs are simply displaced from the psyche; 2) affective saturation, «psychological comprehensibility» of ideas and lack of definitive conviction in those ideas that are understood «based on the experiences, situations and personality of the patient» [11]. Based on precious ideas that dominate in the psyche, drug addicts lose adequate ability to evaluate reality by giving overvaluation to the addiction agent [12]. The presence of precious ideas in the psyche reflects a distortion of the meaning formation mechanism and value regulation disorders of drug addict behavior, which requires further empirical study.

\section{THE AIM}

Therefore, the purpose of this article is to study empirically drug addicts value-meaning sphere disorders.

\section{MATERIALS AND METHODS}

To study the drug addicts value-meaning sphere disorders indicators, Schwarz's «Value Questionnaire» and a structured interview of the respondents, aimed at studying the specifics of their meaning constructs, was used. The study included 60 people undergoing rehabilitation at the Lviv «Life stories» public organization (Ukraine), including 30 drug addicts with up to one year of rehabilitation and 30 drug addicts with one to five years of rehabilitation. The age range of the sample was 18-67 years, the gender composition of the sample was 43 women and 17 men.

\section{RESULTS}

The results of the drug addicts values during the period of rehabilitation indicators study obtained with the help of the Schwartz Value Questionnaire are presented in Table I.

As we can see from the table I, the values of drug addicts in the rehabilitation period (rating from 1 to 3 ) - Universalism, Security and Self-Direction - are of great importance. For them understanding, tolerance, harmony, mutual assistance, purity, sense of belonging, health, stability of society and relationships, independence from others are important in this period of life. The most pronounced, significant types of drug addicts' values are the same as normative ideals («Value Review») and as individual priorities («Personality Profile»).

Consider the results of drug addicts' values during the period of rehabilitation up to one year and from one to five years study (Table II).

As we can see from Table II, at the level of normative ideals («Value Review»), the most pronounced drug ad- 
Table I. The values of drug addicts during rehabilitation $(n=30)$

\begin{tabular}{|c|c|c|c|c|c|}
\hline \multirow{2}{*}{ № } & \multirow{2}{*}{ Values } & \multicolumn{2}{|c|}{ Values Review } & \multicolumn{2}{|c|}{ Personality profile } \\
\hline & & average value & rank position & average value & rank position \\
\hline 1 & Conformity & 16,8 & 6 & 7,8 & 6 \\
\hline 2 & Tradition & 17 & 5 & 7,4 & 7 \\
\hline 3 & Benevolence & 19,4 & 3 & 8,1 & 5 \\
\hline 4 & Universalism & 23,6 & 1 & 11,1 & 1 \\
\hline 5 & Self-Direction & 17,4 & 4 & 8,3 & 4 \\
\hline 6 & Stimulation & 10,5 & 9 & 5,6 & 10 \\
\hline 7 & Hedonism & 8,6 & 10 & 6,5 & 8 \\
\hline 8 & Power & 15,2 & 7 & 8,5 & 3 \\
\hline 9 & Achievement & 14,1 & 8 & 5,9 & 9 \\
\hline 10 & Security & 20,3 & 2 & 9,8 & 2 \\
\hline
\end{tabular}

Table II. The values of drug addicts during the period of rehabilitation up to one year and from one to five years $(n=30)$

\begin{tabular}{|c|c|c|c|c|c|c|c|c|c|}
\hline \multirow[b]{3}{*}{ № } & \multirow[b]{3}{*}{ Values } & \multicolumn{4}{|c|}{ Values Review } & \multicolumn{4}{|c|}{ Personality profile } \\
\hline & & \multicolumn{2}{|c|}{1 group } & \multicolumn{2}{|c|}{2 group } & \multicolumn{2}{|c|}{1 group } & \multicolumn{2}{|c|}{2 group } \\
\hline & & 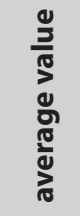 & 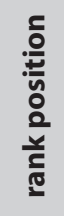 & 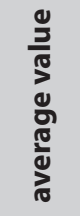 & 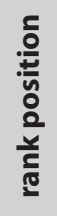 & 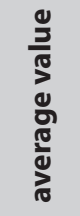 & 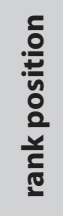 & 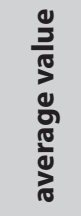 & 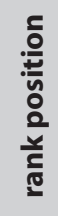 \\
\hline 1 & Conformity & 16,8 & 6 & 17,4 & 6 & 7,8 & 6 & 7,8 & 5 \\
\hline 2 & Tradition & 17 & 5 & 19,4 & 5 & 7,4 & 7 & 7,1 & 7 \\
\hline 3 & Benevolence & 19,4 & 3 & 22,9 & 2 & 8,1 & 5 & 8,2 & 4 \\
\hline 4 & Universalism & 23,6 & 1 & 27,6 & 1 & 11,1 & 1 & 12,2 & 1 \\
\hline 5 & Self-Direction & 17,4 & 4 & 22,2 & 3 & 8,3 & 4 & 8,4 & 3 \\
\hline 6 & Stimulation & 10,5 & 9 & 10,6 & 10 & 5,6 & 10 & 5,3 & 9 \\
\hline 7 & Hedonism & 8,6 & 10 & 11,8 & 9 & 6,5 & 8 & 6,2 & 8 \\
\hline 8 & Power & 15,2 & 7 & 16,9 & 7 & 8,5 & 3 & 7,7 & 6 \\
\hline 9 & Achievement & 14,1 & 8 & 13,3 & 8 & 5,9 & 9 & 3,5 & 10 \\
\hline 10 & Security & 20,3 & 2 & 21,6 & 4 & 9,8 & 2 & 10,5 & 2 \\
\hline
\end{tabular}

Table III. Constructs that reflect a personality's attitude to drug addiction

\begin{tabular}{cc}
\hline Constructs & $\%$ of expression \\
\hline «I am already dead and there is nothing I can change» & $15 \%$ \\
\hline «I was left face to face with my problems» & $12 \%$ \\
\hline «I will lose images of friends who do not use» & $10 \%$ \\
\hline «... desire to live» & $18 \%$ \\
\hline «The drug put me on my knees» & $16 \%$ \\
\hline
\end{tabular}

dicts during the rehabilitation period up to the year types of values (rating from 1 to 3) are Universalism, Security, Benevolence related to the axis of «Self-transcendence» and «Conservatism», and for drug addicts in the period of one to five years - Universalism, Benevolence and Self-Direction, related to the axis of «Self-transcendence» and
«Openness to change». There were statistically significant changes in drug addicts during the period from one to five years values as normative ideals in such types of values as Traditions $(\mathrm{t}=2.04, \mathrm{p} \leq 0.05)$, Benevolence $(\mathrm{t}=2.34$, $\mathrm{p} \leq 0.05)$, Universalism $(\mathrm{t}=2.20, \mathrm{p} \leq 0.05)$, Self-Direction $(\mathrm{t}=3.85, \mathrm{p} \leq 0.001)$ and Hedonism $(\mathrm{t}=3.07, \mathrm{p} \leq 0.001)$. 
Table IV. Positive images of a fixed imagination of drug use and abstinence in human life

\begin{tabular}{|c|c|c|}
\hline Group of images & Image & $\%$ of expression \\
\hline \multirow{6}{*}{ Images of content } & «l'm in sports» & $12 \%$ \\
\hline & «l am healthy and beautiful» & $14 \%$ \\
\hline & «Own car» & $15 \%$ \\
\hline & «Summer project» & $12 \%$ \\
\hline & «Own business» & $18 \%$ \\
\hline & «Holiday in the family» & $21 \%$ \\
\hline \multirow{3}{*}{ Images of use } & «I'm wearing sunglasses with a cigarette» & $18 \%$ \\
\hline & «The whole world is underfoot» & $10 \%$ \\
\hline & «Fun and carefree Self» & $22 \%$ \\
\hline
\end{tabular}

Table V. Addict's myths

\begin{tabular}{cr} 
Myth & \% of expression \\
\hline «The use has a positive psychological effect» & $24 \%$ \\
\hline «Marijuana is not addictive» & $22 \%$ \\
\hline «In some countries, some drugs are allowed, so they can be used» & $21 \%$ \\
\hline «Drug use is an indicator of adulthood. That»s cool!» & $20 \%$ \\
\hline "Controlled usage can be» & $19 \%$ \\
\hline «Addiction is a moral neglect» & $15 \%$ \\
\hline «I want - I drink, I don't want - I don't drink» & $18 \%$ \\
\hline
\end{tabular}

As individual priorities or specific actions ( $«$ Personality Profile»), drug addicts during the period of rehabilitation to the year the most pronounced types of values (rating from 1 to 3) are Universalism, Security, Power, related to the axis of "Self-transcendence», "Conservatism» and «Self-aggrandizement», and for drug addicts in the period of one to five years - Universalism, Security and Self-Direction related to the axis of «Self-transcendence», «Conservatism» and «Openness to change». As individual priorities for drug addicts during the period from one to five years there were statistically significant changes in indicator of Achievement value $(\mathrm{t}=-3.43, \mathrm{p} \leq 0.001)$.

As determined by the theoretical analysis of the problem, the formation of addiction is realized largely due to the influence of fixed imagination images, which participate in the formation of the overvaluation of the addictive agent for the personality and allow to generalize the influence of the agent addiction in the mind of the person.

Based on the results of a structured interview, we also analyzed the most common constructs often used by drug addicts in the process of describing the content of images of their fixed imagination, presented in table III. These constructs reflect the peculiarities of the respondent's meaning sphere, their understanding of the drug addiction process and their life. These constructs are analyzed in the context of fixed imagination images, in the interaction of imaginative and cognitive components of addiction.

As can be seen from Table III, the most commonly used constructs used by drug addicts to describe the role of the drug in their lives reflect a tendency to regard the drug as a source of problems and illnesses in a person's life, a source of loneliness and approaching death as the end of physical existence.

We have analyzed images of fixed imagination that reflect drug use and abstinence patterns obtained through patient's interviewing. In this case, the images of fixed imagination are presented in the form of verbal constructs, describing, in fact, the imaginative images mentioned by respondents in response to the question posed by the experimenter in the form of an image of the attitude to the drug during its use and abstinence from it (Table IV).

As we can see from Table IV, we have noted an important trend of images of fixed imagination, which reflect the state of a drug addicted person in the process of abstinence from drug use - it is activation not only of motives of self-development, improvement of attitude towards oneself, one's health and family, but also financial success, relationships developing, etc.

An important aspect of the study was mediating the role of the image of the fixed imagination through the use of various forms of comprehension and awareness of the process of addiction. We have analyzed the personal myths of drug addicts, viewed from the point of view of systemic family psychotherapy as ways of structuring the experience of the individual, intended, albeit with the help of false determinants, but to ensure the normal functioning of the individual in certain conditions [13]. In this case, we proceeded from the provisions on the symbolic nature of consciousness and the role of mythology in the functioning of the psyche (L. Levy-Bruhl, A.F. Losev, Yu. M. Lotman, 
J. Frazer, K.G. Jung). The personal myths of drug addicts have been diagnosed in the process of interviewing and carrying out a number of projective techniques, discussing the results of their conduct with the respondents, writing their stories of lives (Table V).

As can be seen from Table V, the myths used by drug addicts are mainly about reducing the real harm to the health of the drug use process and exaggerating one's own willful ability to refrain from the drug use process. Also, in myths, there is a reassessment of the positive effect of drug use, which gives freedom, a pleasant feeling, but does not do any harm.

\section{DISCUSSION}

Considering the prevailing values of drug addicts during the rehabilitation period, we can observe a value conflict, correlation of leading types of values to two polar axes of measurement (Table I). The values of Self-Direction that belong to the axis of "Openness to Change» may conflict with the values of Security, which in turn belong to the axis of "Conservatism». Thus, the desire for independence in actions and intentions may be contrary to actions aimed at maintaining the stability of social contacts as well as humility in return to the norm of a healthy life. The value conflict is manifested in the change of one of the leading values as normative ideals - Benevolence belonging to the «Self-Transcendence» axis to the value of the Power belonging to the "Self-Exaltation» axis as values of the social behavior of the individual. That is, drug addiction is characterized by the proclamation of the importance of the well-being and well-being of loved ones, and, in fact, to carry out actions aimed at achieving a dominant position over people. The identified value conflict completes the results of the research by R. R. Garifullin [3] and M. L. Zobin [14].

A comparison of the values during rehabilitation provided the following grounds for analysis. It is clear that at the beginning of rehabilitation work and after a long period it is important for drug addicts to show understanding, tolerance, harmony, mutual help, purity, sense of belonging, the importance of feeling of stability towards openness to a new life experience, independence from one's environment diminishes, thoughts and actions.

Comparing values in the process of rehabilitation also reflects a certain value conflict of drug addicts. Actions aimed at the benefit of loved ones may conflict with self-aggrandizing actions that are characteristic of drug addicts in the primary stages of rehabilitation. And actions aimed at establishing stability may conflict with actions aimed at openness to a new life experience, which is typical for drug addicts during the period of one to five years.

The constructs used by drug addicts focus on the importance of the social environment for the drug addict, because we can observe an additional «anchor» - the importance of friends whose drug addict loses in the course of drug use. This information is important, because it serves as one of the points in the construction of a drug addiction therapy program - through the adoption of a new «Self» that is able to successfully functioning with friends from the past, people, etc. In general, through such constructs and similar verbal constructs, the drug addict first substantiates the importance of the drug in a particular life situation by putting forward "false supports», «incorrectly set coordinates for himself», around which he builds an addiction system. In the future (in the process of use and with the emergence of problems from it), these constructs no longer reflect the preciousness and euphoria of the drug, but more dependent position, its negative impact on the personality's life.

A substantive evaluation of images of a fixed imagination made it possible to reveal such regularity: if in the assessment of personality's (mostly, negative) role of the drug in the life, the fixed imagination had a greater focus on the sensitive side of the individual subjective life, then in the evaluation of the positive side, the abstinence from the use of the fixed imagination tend to improve the attitude towards the self due to activation topics and meanings of health, family and, most importantly, financial success.

Moreover, images of fixed imagination related to abstinence have a more generalized different context - the development of personal space in life, because all the fixed imagination images reflect different aspects of personality in the life of a subject, that was previously a engaged by drug. At the termination of its use, the person is able to «fill» this space with family, finances, self-realization, etc. It is significant that the images of fixed imagination associated with the cessation of drug use in all the subjects have extremely positive emotional color and indicate the formation, in fact, of a new personality's system of value. The question arises as about why this process can be termed as the formation of a new preciousness, because it is about the destruction of addiction - the preciousness of a narcotic substance in a person's life. Such features of comprehension of life correspond to the dependent personality characteristics defined by S. P. Egorchenko [4] and V. D. Mendelevich [5], on the one hand, and emphasize the special role of images of a fixed imagination in the formation of an addictive process - on the other.

The false justifications offered in these myths serve as semantic supports, which have great importance for the formation of preciousness. This importance can be explained as a conscious leveling of the drug role in negative impact on the individual life and health. These misconceptions allow the individual to reduce psychological stress and build a cognitive basis during the addiction period to justify not only the negative impact of the drug, but its positive impact on life.

These myths, being not only cognitive structures, but also triggers of a complex of motivational-affective formations, provoke the value of drug substance in the individual's life. Moreover, the role of such myths in the addictive process is also based on the unconscious common to society mythological tendencies to perceive myths as given by society. For example, as in the myth that in some countries the use of certain drugs is legal, so drug use is safe. It is clear that the generation of this myth combines both: 1 ) distortion of the context (drug use in some countries is implemented for medical purposes and under the control of doctors and 
only in certain cases - for example, cancer) and 2) addressing the collective unconscious in the form of «reference to a significant, but not personalized, point of view» - «some countries», «some people», «some drugs», «some conditions of use» ... But the main idea is that somewhere and in some way they can be consumed, which becomes the central preciousness idea for the drug addict.

\section{CONCLUSIONS}

The results of a study of drug addicts' values in the rehabilitation period revealed great value of Universalism, Security and Self-Direction. The guiding values (Universalism, Security) are unchanged through the rehabilitation period, both as beliefs and as behavioral priorities. In addicts behavior during the rehabilitation period of one to five years the value of the Power decreases and the value of Self-Direction increases.

In the addiction process formation the influence of images of fixed imagination express in a significant role of myths that have the function of a false justification for the safety of drug dependence. The myths used by drug addicts are mainly about reducing the real harm to the health of the drug use process and exaggerating one's own willpower to refrain from the drug use process. At the same time, this publication does not fully exhaust the specifics of the value-meaning sphere of the drug addict and its role in the process of addiction. In particular, the prospect of further exploration of the authors may be the study of drug addicts personal meanings system specifics, the clustering of semantic constructs of this category of subjects, etc.

\section{REFERENCES}

1. Zmanovskaja E.V. Deviantologija (Psihologija otklonjajushhegosja povedenija) : ucheb. posobie dlja stud. vyssh. ucheb. zavedenij [Deviantology (Psychology of deviant behavior): Textbook for high schools]. Moscow: «Academy»; 2003, p. 23-29. (Ru)

2. Bratus' B.S. Psihologicheskij analiz izmenenij lichnosti pri alkogolizme [Psychological analysis of personality changes during alcoholism]. Moscow: Nauka; 1974, p. 102-156. (Ru)

3. Garifullin R.R. Psihokorrekcija smyslovyh struktur narkozavisimoj lichnosti [Psychocorrection of a drug addicted person meaning structures]. (Ph. D. diss.). Kazan'; 2000, p.12-16. (Ru)

4. Egorchenko S.P. Processy smysloobrazovanija, motivacija i mezhlichnostnaja aktivnost' u narkozavisimyh [Meaning processes, motivation and interpersonal activity of drug addicts]. Medical psychology. 2009; 3:31-34. (Ru)

5. Mendelevich V.D. Vlechenie $k$ narkotikam, sverhcennye idei $\mathrm{i}$ sverhcennost'pri narkomanijah [Addiction to drugs, precious ideas and precious drug addiction]. Narcology. 2012; Xl, 4: 90-93. (Ru)

6. Samykina N.Ju., Serebrjakova M.E. Dinamika cennostno-smyslovoj sfery lichnosti v processe narkotizacii: monografija [The dynamics of the personality value-meaning sphere in the process of narcotization: monograph]. Samara : «Univers grupp»; 2007, p.53-64. (Ru)

7. Shherbina L.F. Dinamika smislovih struktur osib, zalezhnih vid psihoaktivnih rechovin, v procesi psihologichnoï reabilitaciï [Persons dependent on psychoactive substances meaning structures dynamics in the process of psychological rehabilitation]. (Ph. D. diss.). Kyiv'; 2004, p.18-27. (Ua)
8. Leshner A.J. Addiction is a brain discase, and in matters. Science. 1997; 5335: 45-47.

9. Fil'c 0. , Sedih K., Mihajliv S. Fiksovana ujava jak mehanizm viniknennja uzalezhnennja [Fixed imagination as a mechanism of dependence]. Psychology and personality. 2018; 2(14):9-22. (Ua)

10. Wernicke C. Grundriss der Psychiatrie in klinischen Vorlesungen. Zweite revidierte Auflage. Verlag von Georg Thieme Leipzig. 1906, p.23-44.

11. Morozov V.M. K voprosu 0 sverhcennyh idejah [To the question of precious ideas]. Proceedings of the P.B. Gannushkin Institute. 1934: 338-349. (Ru)

12. Koljago 0.0. Kliniko-psihopatologicheskaja struktura sindroma sverhcennyh obrazovanij, formirujushhegosja v ramkah jendogennoj depressii [Clinical and psychopathological structure of precious formations syndrome that forms within the framework of endogenous depression]. Psychiatry. 2016; 70(02): 15-20. (Ru)

13. Sedih K. V. Mifologizacija svidomosti jak oznaka suspil'no-politichnoï krizi [The mythologization of consciousness as a sign of socio-political crisis]. Problems of modern psychology. 2015; 6:626-635. (Ua)

14. Zobin M.L. Teoreticheskie modeli addiktivnogo vlechenija: svjaz's mehanizmami zavisimosti i lechenie. Chast' III [Theoretical models of addictive attraction: connection with mechanisms of dependence and treatment. Part III]. Neurological Bulletin. 2012; 1: 49-58. (Ru)

Article is written within the research topic of the Psychology Department of the Poltava V.G. Korolenko National Pedagogical University «Synergistic approach to psychological processes in systems of different level of organization» (state registration number 0117U003062).

\section{ORCID and contributionship:}

Oleksandr O. Filts - 0000-0002-5350-8305 ${ }^{\mathrm{E}}$

Kira V. Sedych - 0000-0003-3528-7569 ${ }^{A, F}$

Vitalii A. Lavrinenko - 0000-0003-4531-7127 ${ }^{C, D}$

Svitlana V. Mychailiv - 0000-0003-1033-0719 ${ }^{B}$

\section{Conflicts of interest:}

Authors declare no conflict of interest.

\section{CORRESPONDING AUTHOR} Vitalii A. Lavrinenko

Zalizna st., 15, ap. 142, 36021, Poltava, Ukraine

tel: +380665331081

e-mail: lavrinenko.vitaliy@gmail.com

Received: 10.07 .2019

Accepted: 05.02.2020

A - Work concept and design, B - Data collection and analysis, C - Responsibility for statistical analysis,

D-Writing the article, E-Critical review, $\mathbf{F}$ - Final approval of the article 